\title{
Inheritance study and linkage mapping of resistance loci to Hemileia vastatrix in Híbrido de Timor UFV 443-03
}

\author{
Kátia Nogueira Pestana ${ }^{1}$ Alexandre Sandri Capucho ${ }^{2} \cdot$ Eveline Teixeira Caixeta $^{3}$. \\ Dênia Pires de Almeida ${ }^{1}$ Eunize Maciel Zambolim ${ }^{1}$ - Cosme Damião $\mathrm{Cruz}^{4}$. \\ Laércio Zambolim $^{5}$ - Antônio Alves Pereira ${ }^{6}$. Antonio Carlos Baião de Oliveira ${ }^{7}$. \\ Ney Sussumu Sakiyama ${ }^{8}$
}

Received: 18 September 2014 / Revised: 26 May 2015 / Accepted: 9 June 2015 / Published online: 26 June 2015

(C) Springer-Verlag Berlin Heidelberg 2015

\begin{abstract}
Coffee leaf rust (CLR) caused by Hemileia vastatrix Berk. et Br. is one of the major Coffea arabica diseases worldwide. CLR resistance has been attributed to at least nine dominant genes, as single or in combination. We present an inheritance study and mapping loci involved in the Híbrido de Timor (HDT) UFV 443-03 resistance to race I, race II, and pathotype 001 of $H$. vastatrix. Molecular markers were used to ascertain the phenotypic results and to map the putative resistance loci. For all tree isolates, the inheritance study indicated that the resistance of HDT UFV 443-03 is conditioned by two independent dominant loci or by three independent loci (two dominant
\end{abstract}

Communicated by D. Grattapaglia

This article is part of the Topical Collection on Disease Resistance

Eveline Teixeira Caixeta

eveline.caixeta@embrapa.br

1 Instituto de Biotecnologia Aplicada à Agropecuária (BIOAGRO), BioCafé, Universidade Federal de Viçosa, Viçosa, MG 36570-000, Brazil

2 Departamento de Fitopatologia, Universidade Federal do Vale do São Francisco, Petrolina, PE 56300-990, Brazil

3 Embrapa Café, BIOAGRO, BioCafé, Universidade Federal de Viçosa, Viçosa, MG 36570-000, Brazil

4 Departamento de Biologia Geral, Universidade Federal de Viçosa, Viçosa, MG 36570-000, Brazil

5 Departamento de Fitopatologia, Universidade Federal de Viçosa, Viçosa, MG 36570-000, Brazil

6 Empresa de Pesquisa Agropecuária de Minas Gerais (EPAMIG), Viçosa, MG 36570-000, Brazil

7 Embrapa Café, EPAMIG, Viçosa, MG 36570-000, Brazil

8 Departamento de Fitotecnia, Universidade Federal de Viçosa, Viçosa, MG 36570-000, Brazil and one recessive). Molecular marker analyses ascertained that the resistance of HDT UFV 443-03 to race II is conditioned by at least two independent dominant loci, while the resistance to race I and pathotype 001 is conditioned by at least four independent dominant loci. Gene pyramiding might result in a cultivar with durable resistance; however, it is difficult to distinguish between plants with one or more resistance genes due to epistatic effects. Molecular markers linked to these genes were indicated for marker-assisted selection, as it is an efficient breeding alternative for CLR resistance with no such epistatic effects.

Keywords Coffee $\cdot$ Leaf rust $\cdot$ Breeding $\cdot$ MAS $\cdot$ Linkage map $\cdot$ QTL

\section{Introduction}

Two out of 104 Coffea species are economically important: Coffea arabica L. (arabica coffee) and Coffea canephora Pierre ex A. Froehner (robusta coffee). C. arabica presents higher cup quality than $C$. canephora. C. arabica is autogamous and allotetraploid $(2 n=44)$, while $C$. canephora is allogamous and diploid $(2 n=22)$. C. canephora presents higher general genetic variability than $C$. arabica (Lashermes et al. 1999; de Kochko et al. 2010).

Coffee leaf rust caused by Hemileia vastatrix Berk. et Br. is one of the major $C$. arabica diseases worldwide. This fungus attacks leaves, causing severe yield losses. Coffee tree resistance to $H$. vastatrix has been attributed to at least nine dominant genes $\left(S_{\mathrm{H}} 1\right.$ to $\left.\mathrm{S}_{\mathrm{H}} 9\right)$, as single or in combination. C. arabica is a source of $\mathrm{S}_{\mathrm{H}} 1, \mathrm{~S}_{\mathrm{H}} 2, \mathrm{~S}_{\mathrm{H}} 4$, and $\mathrm{S}_{\mathrm{H}} 5$; Coffea liberica of $\mathrm{S}_{\mathrm{H}} 3$; and C. canephora of $\mathrm{S}_{\mathrm{H}} 6, \mathrm{~S}_{\mathrm{H}} 7, \mathrm{~S}_{\mathrm{H}} 8$, and $\mathrm{S}_{\mathrm{H}} 9$ (Wagner and Bettencourt 1965; Noronha-Wagner and Bettencourt 1967; Bettencourt and Carvalho 1968; Bettencourt and Noronha-Wagner 1971; Bettencourt et al. 
1980; Bettencourt and Rodrigues 1988). Other major and minor genes of $C$. canephora may condition coffee leaf rust (CLR) resistance (Rodrigues et al. 1975; Eskes and Da Costa 1983; Bettencourt and Rodrigues 1988; Eskes et al. 1990; Várzea and Marques 2005; Herrera et al. 2009; Romero et al. 2010, 2014).

The use of CLR cultivars is efficient, cheap, and environmentally safe. However, host resistance may be overcome by new races of $H$. vastatrix, as a consequence of high variability of this biotrophic fungus and selection pressure (Zambolim et al. 1999; Várzea and Marques 2005; Cabral et al. 2009; Maia et al. 2013). $\mathrm{S}_{\mathrm{H}} 1, \mathrm{~S}_{\mathrm{H}} 2, \mathrm{~S}_{\mathrm{H}} 4$, and $\mathrm{S}_{\mathrm{H}} 5$ genes of C. arabica, for instance, were already overcome by existing rust races (Owuor and Van der Vossen 1981; Berthaud and Charrier 1988). $\mathrm{S}_{\mathrm{H}} 6, \mathrm{~S}_{\mathrm{H}} 7, \mathrm{~S}_{\mathrm{H}} 8$, and $\mathrm{S}_{\mathrm{H}} 9$ identified in a Híbrido de Timor (HDT) population, derived from a C. arabica $\times$ C. canephora spontaneous cross (Bettencourt et al. 1980, 1992), have been successfully used to breed C. arabica for $H$. vastatrix resistance. Many introductions of HDT selections were made in Brazil, by vegetative propagation or by means of samples of seeds collected in coffee trees selected in the Centro de Investigações das Ferrugens do Cafeeiro (CIFC), Portugal, and experimental stations of Angola (e.g., UFV 443-03 introduced by seeds from Estação Regional de Uige (ERU), Angola). This germplasm contain different numbers of rust-resistant genes that are not characterized yet. Despite the importance of these germplasms, the cultivars derived from HDT are gradually losing the resistance to rust in Brazil and other countries, due to the development of new virulent races (Várzea and Marques 2005).

Gene stacking or pyramiding might result in cultivars with a more durable resistance compared to cultivars with single racespecific resistance gene. In conventional breeding, a segregating coffee population inoculated with physiologic race of $H$. vastatrix can be easily screened for resistance. However, it is difficult to distinguish between plants with one or more resistance genes due to epistatic effects. Since molecular markers show no such epistatic effects, marker-assisted selection (MAS) can be an efficient alternative. MAS requires no phenotyping but requires previous development of molecular markers linked to each gene under selection (Caixeta et al. 2009).

Saturated genetic linkage maps of $C$. arabica should be useful for mapping resistance genes and to identify markers linked to those genes. However, they are not yet available due to low molecular polymorphism and the polyploidy nature of this species. Despite these constraints, few studies have attempted to map molecular markers linked to $H$. vastatrix resistance genes. In a $\mathrm{F}_{2}$ population, introgression analysis of $\mathrm{S}_{\mathrm{H}} 3$ from C. liberica into C. arabica resulted in 21 amplified fragment length polymorphism (AFLP)-linked markers (Prakash et al. 2004). Additional analysis resulted in two sequence-characterized genetic markers that co-segregated perfectly with $\mathrm{S}_{\mathrm{H}} 3$, thus suitable for MAS and gene pyramiding (Mahé et al. 2008). A resistance gene of HDT UFV 427-15 to race II of $H$. vastatrix was mapped with two AFLP markers (Brito et al. 2010). Subsequently, the same gene was mapped with six sequence-characterized amplified region (SCAR) markers delimiting a chromosome region of $9.4 \mathrm{cM}$ and flanking the resistance gene by 0.7 and $0.9 \mathrm{cM}$ (Diola et al. 2011). The analysis of $\mathrm{a}_{2}$ population resulted in five AFLP and two single sequence repeat (SSR) markers associated with partial resistance of a HDT-derived line (Herrera et al. 2009). Additional analysis of the same population resulted in a quantitative trait locus (QTL) mapped between two SSR markers within the interval of $2.5 \mathrm{cM}$ (Romero et al. 2014).

We now present an inheritance study of HDT UFV 443-03 resistance to races I and II and to pathotype 001 described below of $H$. vastatrix. Molecular markers were used to ascertain the phenotypic results and to map the putative resistance loci.

\section{Material and methods}

\section{Plant material}

Three segregating populations derived from crossing Catuaí Amarelo IAC 64 (UFV 2148-57) (susceptible parent) and Híbrido de Timor UFV 443-03 (resistant parent) were used in this study. The HDT UFV 443-03 is an important rustresistant source used in breeding programs, although their genes have not yet been characterized. UFV 443-03 was introduced in Brazil by seeds from U209/7 plant of ERU, Angola, which was derived by seeds from CIFC 2570 plant of CIFC, Portugal. The $\mathrm{F}_{1}$ plant, designated H-511-1, was self-crossed under controlled conditions to obtain the segregating $\mathrm{F}_{2}$ population (247 individuals). In addition, the $\mathrm{F}_{1}$ plant was backcrossed with HDT UFV 443-03 and with Catuaí Amarelo IAC 64, generating 87 backcrossed plants with the resistant parent $(\mathrm{BCr})$ and 115 backcrossed plants with the susceptible parent (BCs).

\section{Phenotypic data}

Races I and II and pathotype 001 of H. vastatrix, which show contrasting reactions between Catuaí Amarelo IAC 64 (susceptible) and HDT UFV 443-03 (resistant), were used in this study. Races I and II were collected from commercial fields of Catuaí Vermelho and the pathotype 001 from Oeiras cultivar. Races I and II were characterized in a series of differentiating coffee clones, as described by Capucho et al. (2012). The pathotype 001 breaks down the resistance of Oeiras (HDT CIFC $832 / 1 \times$ Caturra CIFC 19/1) released as a rust-resistant cultivar. It also breaks down the resistance of Icatu Vermelho $(C$. arabica $\times C$. canephora $)$. Pathotype 001 
was characterized in a series of differentiating coffee clones as race II. Since all known isolates of race II do not infect Oeiras and Icatu Vermelho, pathotype 001 should carry additional virulence genes not detected by the differentiating clones (Capucho et al. 2009).

Uredospores of the fungus were multiplied and used as an inoculum according to methodology described by Capucho et al. (2009). Parents, $F_{1}$, and all 449 segregating plants (247 $\mathrm{F}_{2}, 87 \mathrm{BCr}$, and $115 \mathrm{BCs}$ ) were inoculated using a leaf disc method described by Eskes (1982), with three replications.

The symptom evaluation (phenotyping) was performed according to Capucho et al. (2009), using a scale (scores 1 to 6) described by Tamayo et al. (1995), based on the absence or presence of uredospores. The phenotypes were scored as follows: no symptoms (score 1), small chlorotic injuries (score 2), large chlorotic injuries without sporulation (score 3), large chlorotic injuries with small sporulation occupying less than $25 \%$ of the area (score 4 ), injuries with sporulation occupying from 25 to $50 \%$ of the area (score 5), and injuries with sporulation occupying more than $50 \%$ of the area (score 6 ). The maximum score of three replications was used to represent the symptom of each plant.

\section{Inheritance study}

For inheritance study, resistant plants were scored 1 to 3 and susceptible plants were scored 4 to 6 , according to the scale described by Tamayo et al. (1995).

Phenotypic segregation ratios of $\mathrm{F}_{2}$ and $\mathrm{BCs}$ populations were chi-square $\left(\chi^{2}\right)$ tested, using GENES software (Cruz 2013). Estimated $P$ value $>0.05$ does not reject the hypothesis. Expected $\mathrm{F}_{2}$ ratios (resistant/susceptible) were tested for one locus (3:1 and 1:3), two loci $(15: 1,13: 3,7: 9,9: 7,3: 13$, and $1: 15)$, and three loci $(63: 1,61: 3,55: 9,37: 27,27: 37,9: 55$, $3: 61,1: 63,57: 7,51: 13,49: 15,43: 21,25: 39$, and 19:45). Expected BCs ratios were tested for one locus (1:1) and two or three loci (3:1).

\section{Molecular marker study}

A linkage map constructed with molecular markers allowed us to use the QTL mapping technique to ascertain the previous inheritance study results and to map putative resistance loci.

\section{DNA extraction}

DNA extraction of parents (Catuaí Amarelo IAC 64 and HDT UFV 443-03), $F_{1}$ (H 511-1), and $247 \mathrm{~F}_{2}$ plants was performed according to Diniz et al. (2005). DNA was quality controlled on agarose gel (1\%) and quantified with Thermo Scientific NanoDrop 2000 Spectrophotometer. Final DNA concentration was adjusted to $25 \mathrm{ng} / \mu \mathrm{L}$ and freezer stored at $-20{ }^{\circ} \mathrm{C}$.

\section{SSR marker data}

A preliminary polymorphism survey of SSR markers was performed with DNA samples over the parents and $10 \mathrm{~F}_{2}$ plants using 373 coffee SSR primers (Combes et al. 2000; Rovelli et al. 2000; Baruah et al. 2003; Coulibaly et al. 2003; Moncada and McCouch 2004; Poncet et al. 2004; Bhat et al. 2005; Hendre et al. 2008; Missio et al. 2009b, 2011; Ferrão et al. 2015). Polymorphic SSR markers were then selected and surveyed with the entire $\mathrm{F}_{2}$ population. Polymerase chain reaction (PCR) was performed according to Missio et al. (2009a), and SSR polymorphisms were observed in $6 \%$ polyacrylamide denaturing gel stained with silver nitrate, as described by Brito et al. (2010). The polymorphisms were alternatively observed by DNA sequencing with an ABI 3130xl Genetic Analyzer (Applied Biosystems). Each SSR locus was first amplified by PCR, using a forward primer labeled with a specific fluorophore [6-FAM (blue) or NED (yellow) or HEX (green)]. PCR reactions with each primer pair were performed separately, and the reactions of the three specific fluorophores were mixed, characterizing a pseudo-multiplex. Each PCR product solution was diluted at a 1:10 ratio, and $1 \mu \mathrm{L}$ of each diluted reaction was transferred to a special sequencing plate containing $6.8 \mu \mathrm{L}$ of formamide HI-DI (Applied Biosystems) and $0.2 \mu \mathrm{L}$ of Rox 500 (standard molecular weight labeled with RED fluorophore). The DNA was denatured in a thermocycler at $95{ }^{\circ} \mathrm{C}$ for $3 \mathrm{~min}$. The samples were electroinjected into the sequencer, into a 50 -cm-length silica capillary with $50 \mu \mathrm{m}$ in diameter filled with POP 7 polymer, following the manufacturer's recommendation. The DNA fragments were analyzed using GeneMapper V4.1 software (Applied Biosystems).

\section{AFLP marker data}

AFLP markers were generated as described by Brito et al. (2010), with modifications. DNA samples of parents (HDT UFV 443-03 and Catuaí Amarelo IAC 64) and $\mathrm{F}_{2}$ individuals were digested with $E c o$ RI and $M s e I$ restriction enzymes for $8 \mathrm{~h}$ at $37^{\circ} \mathrm{C}$. DNA fragments were linked to specific adaptors, using T4 DNA ligase for $14 \mathrm{~h}$ at $4{ }^{\circ} \mathrm{C}$. The solution was diluted 1:10 in TE (pH 8.0) and stored at $-20^{\circ} \mathrm{C}$. Pre-selective PCR amplification was performed with primers complementary to the adaptors that contained an additional nucleotide $(\mathrm{N})$ at the $3^{\prime}$ terminus. The pre-amplified product was diluted 1:40 in TE (pH 8.0) and stored at $-20^{\circ} \mathrm{C}$. Seventeen combinations of selective primers resulting from $E c o$ RI and $M s e I$ were used for PCR amplification: E-CAG/M-TGC, E-CAT/M-AGT, ECCT/M-ATA, E-CCC/M-AGC, E-CCC/M-AGA, E-CGA/MACA, E-CGG/M-ACG, E-CGT/M-TCT, E-CGA/M-TCC, ECGC/M-ATA, E-CGT/M-ATC, E-CTG/M-AAT, E-CTG/MTAC, E-CTT/M-TGC, E-CTC/M-AGT, E-CTC/M-AAG, and E-CTT/MTCG. Eight microliters of formamide $(98 \%$ 
formamide, $10 \mathrm{mM}$ EDTA ( $\mathrm{pH}$ 8.0), $1 \mathrm{mg} / \mathrm{mL}$ xylene cyanol, and $1 \mathrm{mg} / \mathrm{mL}$ bromophenol blue) was added to the amplified product solutions. AFLP markers were observed in denaturing polyacrylamide gels (6\%), stained with silver nitrate.

\section{Random amplified polymorphic DNA marker data}

Forty-six primers from Operon Technologies were used to generate random amplified polymorphic DNA (RAPD) markers by PCR, as described by Ferrão et al. (2013). PCR was performed with a $25 \mu \mathrm{L}$ solution containing $25 \mathrm{ng}$ genomic DNA, 1 U Taq DNA polymerase, $0.1 \mathrm{mM}$ of each dNTP, $0.2 \mu \mathrm{M}$ of primer, $50 \mathrm{mM} \mathrm{KCl}, 10 \mathrm{mM}$ Tris- $\mathrm{HCl}(\mathrm{pH} 8.3)$, $2 \mathrm{mM} \mathrm{MgCl}_{2}$, and Milli-Q sterile water. RAPD markers were observed under UV light in $1.2 \%$ agarose gels stained with ethidium bromide.

\section{CARF 005 marker}

CARF 005 marker was used as describes by Alvarenga et al. (2011). This marker was developed from mined sequences of the Brazilian Coffee Genome Project to differentiate the presence/absence of a band between coffee plants that were resistant or susceptible to $H$. vastatrix. It amplifies a sequence that corresponds to a resistance gene fragment with annotation gi|24459841|emb|CAC82597.1| "disease resistance-like protein" of C. arabica.

\section{Linkage map}

The linkage map was constructed with $247 \mathrm{~F}_{2}$ plants using SSR, AFLP, RAPD, and CARF 005 polymorphic markers.

Marker data were encoded and analyzed using GQMOL software (Cruz 2008). The line graphs of linkage groups were constructed using MapChart software (Voorrips 2002). Mendelian segregation (3:1) for each marker was evaluated using a chi-square test $\left(\chi^{2}\right)(P=0.05$, linkage group (LG) 1$)$ using Bonferroni correction. SSRs were scored as dominant markers. Markers with segregation distortion were included in the map if they did not change the linkage order of markers without distortion.

Linkage groups were formed with a minimum logarithm of likelihood ratio (LOD score) of 3.0 and maximum recombination of $30 \%$. Genetic distance in centiMorgans $(\mathrm{cM})$ was calculated based on estimated recombination frequencies and a Morgan map function.

\section{Mendelian factor location}

The QTL mapping technique was originally designed for mapping Mendelian factors underlying quantitative traits (Lander and Botstein 1989). The same technique was used for mapping Mendelian factors underlying a qualitative trait,
CLR resistance, which allowed us to ascertain the previous inheritance study of this trait and to develop molecular markers linked to the putative loci. We assumed that QTLs corresponded to large effect loci.

For QTL mapping, plants were scored 1 to 6 according to the scale described by Tamayo et al. (1995). The statistical analyses were performed as described by Lander and Botstein (1989), using GQMOL software (Cruz 2008). Simple interval method was used with regression analysis. A QTL determination coefficient $\left(R^{2}\right)$ corresponded to the peak of large QTL significance, adopting a LOD score value higher than 3.0. $R^{2}$ expressed the percentage of phenotypic variation explained using a QTL.

To ascertain the previous inheritance study results, the following data were analyzed for each QTL: additive effect $(a)$, dominance effect $(d)$, average degree of dominance $(k)$, allelic interaction, average of disease severity, and mean severity reduction.

Average degree of dominance $(k)$ was estimated according to the formula $k=|d| /|a|$, indicating the following allelic interaction possibilities for a marker associated with QTL: absence of dominance (AD) if $k=0$, partial dominance (PD) if $0<k<$ 1.0 , complete dominance (CD) if $k=1.0$, and overdominance (OD) if $k>1.0$.

Average disease severity and mean severity reduction were calculated to estimate the effect of each QTL in the resistance. The average disease severity (based on scores 1 to 6 of leaf rust symptoms) was calculated for a group of plants presenting a marker linked to a QTL and compared with the average disease severity of a group of plants without the same marker. The comparison method of simple marker was performed using $F$ test $(P=0.05)$, with GQMOL software (Cruz 2008). Mean severity reduction associated with the presence of a marker linked to a QTL was calculated in percentage.

\section{Results}

\section{Inheritance study}

HDT UFV 443-03, $\mathrm{F}_{1}$, and BCr plants were all resistant (score 1) to races I and II and to pathotype 001 of $H$. vastatrix, while Catuaí Amarelo IAC 64 was susceptible (score 6). The graphic distribution of $\mathrm{F}_{2}$ plants according to the symptom (scores $1,2,3,4,5$, or 6 ) showed the predominance of resistant plants (score 1, 2, and 3) in the population (Fig. 1). These results indicated that the resistance of HDT UFV 443-03 to all three pathogen isolates presents dominance effect.

$\mathrm{F}_{2}$ and $\mathrm{BCs}$ populations showed phenotypic segregation for resistance (scores 1 to 3 ) and susceptibility (scores 4 to 6) to all three isolates of $H$. vastatrix (Table 1 ). $F_{2}$ population inoculated with race I of the pathogen presented 226 resistant 


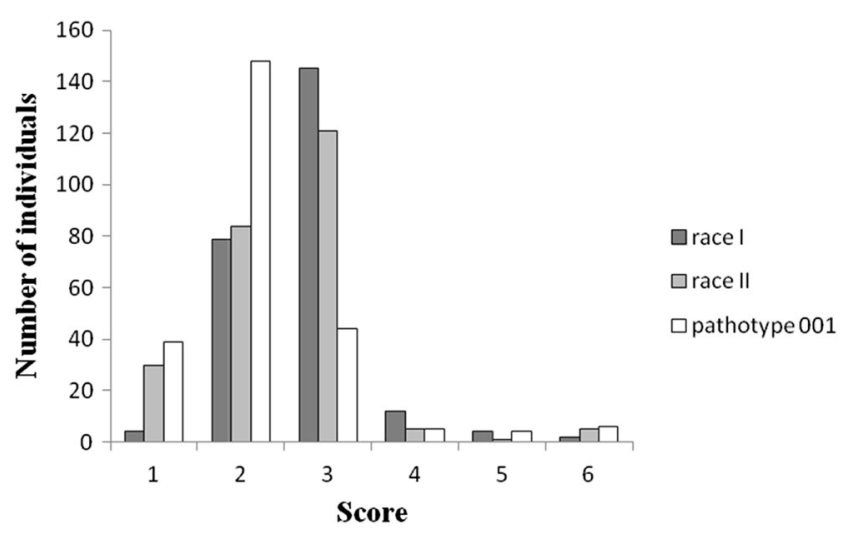

Fig. 1 Frequency of $\mathrm{F}_{2}$ coffee plants, following the scale of Tamayo et al. (1995). Resistant individuals (1-3) and susceptible (4-6) are shown. 1 absence of symptoms, 2 small chlorotic injuries, 3 large chlorotic injuries without sporulation, 4 large chlorotic injuries with few uredospores occupying less than $25 \%$ of the injury area, 5 injuries with sporulation occupying from 25 to $50 \%$ of the area, 6 injuries with sporulation occupying more than $50 \%$ of the area with uredospores and 17 susceptible plants, and BCs population presented 84 resistant and 30 susceptible plants. With race II inoculation, $F_{2}$ population presented 235 resistant and 11 susceptible plants and BCs population presented 80 resistant and 35 susceptible plants. With pathotype 001 inoculation, $\mathrm{F}_{2}$ population presented 231 resistant and 15 susceptible plants and BCs population presented 85 resistant and 30 susceptible plants. For all the three isolates of $H$. vastatrix, the following expected phenotypic segregation ratios were confirmed using $\chi^{2}$ test $(P>0.05)$ : 15:1 (two dominant independent loci) and 61:3 (two dominant loci and one recessive independent locus) for $\mathrm{F}_{2}$ populations and 3:1 (two dominant independent loci or two dominant loci and one recessive independent locus) for BCs populations.

These results indicated, for all the three isolates, two inheritance possibilities: (1) the resistance of HDT UFV 443-03 is conditioned by at least two independent dominant loci, or (2)
Table 1 Expected and observed ratios for two and three loci responsible for resistance, in progenitors, $\mathrm{F}_{1}$ and $\mathrm{F}_{2}$ population, resistant backcrossing $(\mathrm{BCr})$, and susceptible backcrossing (BCs)

\begin{tabular}{|c|c|c|c|c|c|c|c|c|}
\hline \multirow[t]{2}{*}{ Population } & \multicolumn{2}{|c|}{ Expected ratio } & \multicolumn{2}{|c|}{ Observed number } & \multicolumn{2}{|c|}{ Expected number } & \multirow[t]{2}{*}{$\chi^{2}$} & \multirow[t]{2}{*}{ Probability $(\%)$} \\
\hline & $\mathrm{R}$ & $\mathrm{S}$ & $\mathrm{R}$ & S & $\mathrm{R}$ & $\mathrm{S}$ & & \\
\hline \multicolumn{9}{|l|}{ Race I } \\
\hline UFV 443-03 & 1 & 0 & 1 & 0 & 1 & 0 & - & - \\
\hline UFV 2148-57 & 0 & 1 & 0 & 1 & 0 & 1 & - & - \\
\hline $\mathrm{F}_{1}$ & 1 & 0 & 1 & 0 & 1 & 0 & - & - \\
\hline $\mathrm{BCr}^{\mathrm{a}}$ & 1 & 0 & 87 & 0 & 87 & 0 & - & - \\
\hline $\mathrm{F}_{2}$ & $15^{\mathrm{b}}$ & 1 & 226 & 17 & 227.8 & 15.2 & 0.23 & 63.1 \\
\hline $\mathrm{F}_{2}$ & $61^{\mathrm{c}}$ & 3 & 226 & 17 & 231.6 & 11.4 & 2.90 & 8.9 \\
\hline $\mathrm{BCs}^{\mathrm{d}}$ & $3^{\mathrm{e}}$ & 1 & 84 & 30 & 85.5 & 28.5 & 0.10 & 74.6 \\
\hline \multicolumn{9}{|l|}{ Race II } \\
\hline UFV 443-03 & 1 & 0 & 1 & 0 & 1 & 0 & - & - \\
\hline UFV 2148-57 & 0 & 1 & 0 & 1 & 0 & 1 & - & - \\
\hline $\mathrm{F}_{1}$ & 1 & 0 & 1 & 0 & 1 & 0 & - & - \\
\hline $\mathrm{BCr}^{\mathrm{a}}$ & 1 & 0 & 87 & 0 & 87 & 0 & - & - \\
\hline $\mathrm{F}_{2}$ & $15^{\mathrm{b}}$ & 1 & 235 & 11 & 230.6 & 15.4 & 1.33 & 24.9 \\
\hline $\mathrm{F}_{2}$ & $61^{\mathrm{c}}$ & 3 & 235 & 11 & 234.5 & 11.5 & 0.02 & 87.3 \\
\hline $\mathrm{BCs}^{\mathrm{d}}$ & $3^{\mathrm{e}}$ & 1 & 80 & 35 & 86.25 & 28.75 & 1.81 & 17.8 \\
\hline \multicolumn{9}{|l|}{ Pathotype 001} \\
\hline UFV 443-03 & 1 & 0 & 1 & 0 & 1 & 0 & - & - \\
\hline UFV 2148-57 & 0 & 1 & 0 & 1 & 0 & 1 & - & - \\
\hline $\mathrm{F}_{1}$ & 1 & 0 & 1 & 0 & 1 & 0 & - & - \\
\hline $\mathrm{BCr}^{\mathrm{a}}$ & 1 & 0 & 87 & 0 & 87 & 0 & - & - \\
\hline $\mathrm{F}_{2}$ & $15^{\mathrm{b}}$ & 1 & 231 & 15 & 230.6 & 15.4 & 0.009 & 92.1 \\
\hline $\mathrm{F}_{2}$ & $61^{\mathrm{c}}$ & 3 & 231 & 15 & 234.5 & 11.5 & 1.09 & 29.5 \\
\hline $\mathrm{BCs}^{\mathrm{d}}$ & $3^{\mathrm{e}}$ & 1 & 85 & 30 & 86.25 & 28.75 & 0.07 & 78.8 \\
\hline
\end{tabular}

$R$ resistant plants, $S$ susceptible plants, $\chi^{2}$ chi-square

${ }^{\text {a }}$ Resistant backcrossing

${ }^{\mathrm{b}}$ Expected ratio for two loci $\left(15: 1\right.$, in generation $\left.\mathrm{F}_{2}\right)$

${ }^{\mathrm{c}}$ Expected ratio for three loci $\left(61: 3\right.$, in generation $\left.\mathrm{F}_{2}\right)$

${ }^{\mathrm{d}}$ Susceptible backcrossing

${ }^{\mathrm{e}}$ Expected ratio for two and three loci in susceptible backcrossing 
the resistance is conditioned by at least three independent loci (two dominant loci and one recessive locus).

\section{Molecular marker study}

\section{SSR, AFLP, RAPD, and CARF 005 data}

SSR markers were tested for polymorphism between Catuaí Amarelo IAC 64 (susceptible parent) and HDT UFV 443-03 (resistant parent) with 373 pairs of primers. There were $58(15.5 \%)$ polymorphic and 271 monomorphic SSR markers $(72.7 \%)$, whereas $44(11.8 \%)$ failed to amplify. Those polymorphic SSR markers were tested with $\mathrm{F}_{2}$ population.

Seventeen combinations of selective AFLP primers generated 74 polymorphic markers when tested with parents and $\mathrm{F}_{2}$ population. AFLP markers presented an average of 4.3 polymorphic bands per pair of primers.

Forty-six RAPD primers generated four polymorphic markers when tested with parents and $F_{2}$ population, with one polymorphic band/primer.

CARF 005 marker was polymorphic for parents and $F_{2}$ population.

\section{Linkage map}

A set of 137 polymorphic markers (58 SSR, 74 AFLP, 4 RAPD, and 1 CARF 005) was used to assay a segregant population of $247 \mathrm{~F}_{2}$ plants. Twenty-one markers (12 AFLP, 8 SSR, and 1 CARF 005) presented segregation ratio distortion ( $15.3 \%$ distortion).

A linkage map was constructed with 111 markers distributed in 12 LGs (Fig. 2, Table 2), while 26 markers (12 AFLP, 13 SSR, and 1 CARF 005) did not link to any of the groups. The SSR markers mapped are presented in Table 3.

The map encompassed $976.8 \mathrm{cM}$ of the genome. Linkage group size ranged from $18.4 \mathrm{cM}$ (LG 12) to $234.6 \mathrm{cM}$ (LG 1). The distance between two adjacent markers (interval) varied from $0 \mathrm{cM}$ (i.e., two completely linked markers) to $29.4 \mathrm{cM}$, with the average distance of $9.9 \mathrm{cM}$. Most intervals $(75.7 \%)$ did not exceed $20 \mathrm{cM}$. The mean distance between markers within each linkage group varied from $5.3 \mathrm{cM}$ (LG 5) to $20.1 \mathrm{cM}$ (LG 10).

\section{Mendelian factor location}

As described in the previous section, the inheritance study indicated that resistance of HDT UFV 443-03 is conditioned
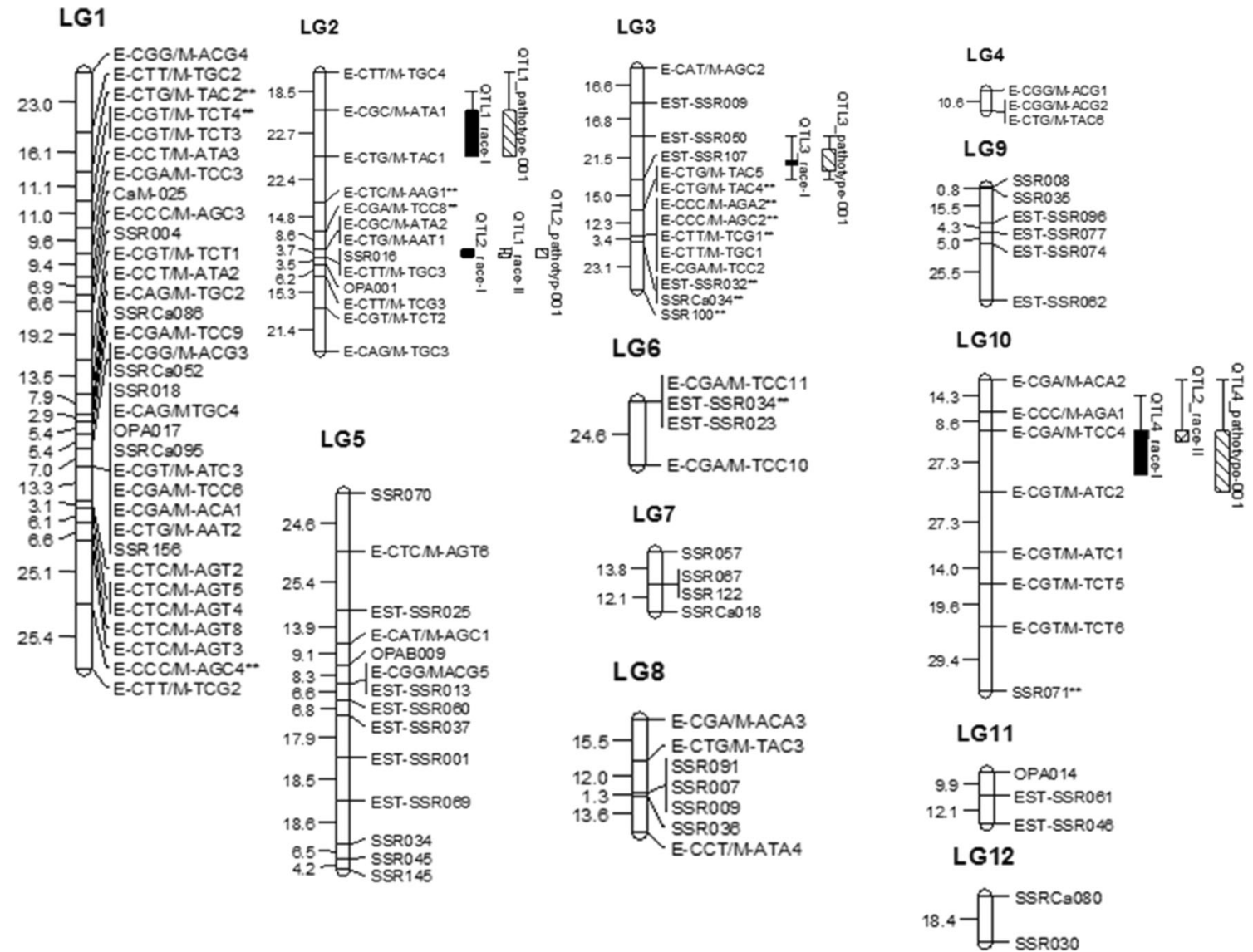

Fig. 2 Linkage map for C. arabica containing 111 markers. On the right of bar are names of molecular markers and on the left distances in centiMorgans. Bars beside marker name indicate QTL positions for race I, race II, and pathotype 001 
Table 2 Summary of linkage map for the $\mathrm{F}_{2}$ population of C. arabica

\begin{tabular}{lclllllll}
\hline LG & Length $(\mathrm{cM})$ & Number $^{\mathrm{a}}$ & AFLP & SSR & RAPD & RGA & Mean distance $^{\mathrm{b}}(\mathrm{cM})$ & Minimum and maximum distance $^{\mathrm{c}}(\mathrm{cM})$ \\
\hline 1 & 234.6 & 33 & 25 & 7 & 1 & - & 7.3 & $0.0-25.4$ \\
2 & 137.1 & 13 & 11 & 1 & 1 & - & 11.4 & $0.0-22.7$ \\
3 & 108.7 & 14 & 8 & 6 & - & - & 8.4 & $0.0-23.1$ \\
4 & 10.6 & 3 & 3 & - & - & - & 5.3 & $0.0-10.6$ \\
5 & 160.4 & 14 & 3 & 10 & 1 & - & 13.4 & $0.0-25.4$ \\
6 & 24.6 & 4 & 2 & 2 & - & - & 8.2 & $0.0-24.6$ \\
7 & 25.9 & 4 & - & 4 & - & - & 8.6 & $0.0-13.8$ \\
8 & 42.4 & 7 & 3 & 4 & - & - & 7.1 & $0.0-15.5$ \\
9 & 51.1 & 6 & - & 6 & - & - & 10.2 & $0.8-25.6$ \\
10 & 140.5 & 8 & 7 & 1 & - & - & 20.1 & $8.6-29.4$ \\
11 & 22.0 & 3 & - & 2 & 1 & - & 11.0 & $9.9-12.1$ \\
12 & 18.4 & 2 & - & 2 & - & - & 18.4 & $0.0-29.4$ \\
General $^{2}$ & 976.8 & 111 & 62 & 45 & 4 & - & 9.9 & \\
NL & & 26 & 12 & 13 & - & 1 & & \\
Distor. & & 21 & 12 & 8 & - & 1 & & \\
\hline
\end{tabular}

$L G$ linkage group, $c M$ unit in centiMorgans

${ }^{a}$ Number of markers

${ }^{\mathrm{b}}$ Mean distance between markers

${ }^{\mathrm{c}}$ Minimum and maximum distance between markers

${ }^{\mathrm{d}}$ Not linked markers

${ }^{\mathrm{e}}$ Distorted markers

by at least two independent dominant loci or by at least three independent loci (two dominant loci and one recessive locus). Molecular data below were used to ascertain these results.

Four independent QTLs were associated with CLR resistance to race I and pathotype 001. Two independent QTLs were associated with CLR resistance to race II (Fig. 2, Table 4).

For every QTL, the average disease severity of a group of plants presenting a marker linked to the QTL was lower than that of the group without the same marker. Every marker linked to a QTL was a HDT UFV 443-03 (resistant parent)derived marker. The mean severity reduction associated with the presence of a marker linked to a QTL ranged from 4.1 to $31.0 \%$ (Table 4).

All allelic interactions (Table 4) showed dominance effect (CD, PD, or OD), confirming the inheritance study of earlier section, which indicated that the resistance is conditioned by dominant genes. No allelic interaction showing absence of dominance $(\mathrm{AD})$ was observed, indicating no recessive gene action evidence conditioning the resistance. Consequently, the second hypothesis of inheritance study was rejected.

Therefore, the molecular marker analyses ascertained that the resistance of HDT UFV 443-03 to race II of $H$. vastatrix is conditioned by two independent dominant loci (mapped as two independent QTLs). However, the molecular analyses also indicated that the resistance to race I and pathotype 001 is conditioned by four independent dominant loci (mapped as four independent QTLs), while the inheritance study indicated that the resistance is conditioned by two independent dominant loci. These results are discussed in the next section.

Four independent QTLs were associated with CLR resistance to race I (Fig. 2, Table 4): QTL1_raça-1 mapped in LG 2, at $22.7 \mathrm{cM}$ from marker E-CGC/M-ATA 1, explaining $9.1 \%$ of the phenotypic variation; QTL2_raça-I mapped in LG 2, at $3.0 \mathrm{cM}$ from marker E-CTG/M-AAT 1, explaining $8.9 \%$ of the phenotypic variation; QTL3 raça-I mapped in LG 3, at $13.0 \mathrm{cM}$ from marker EST-SSR 050, explaining $5.7 \%$ of phenotypic variation; and QTL4_raça-I mapped in LG 10, at $12.0 \mathrm{cM}$ from E-CGA/M-TCC 4, explaining $7.8 \%$ of phenotypic variation.

Two independent QTLs were associated with CLR resistance to race II (Fig. 2, Table 4): QTL1_raça-II mapped in LG 2, at $3.7 \mathrm{cM}$ from marker E-CTG/M-AAT 1, explaining 5.8 \% of the phenotypic variation, and QTL2_raça-II mapped in LG 10 , at $8.0 \mathrm{cM}$ from marker E-CCC/M-AGA1, explaining $8.1 \%$ of the phenotypic variation.

Four independent QTLs were associated with CLR resistance to pathotype 001 (Fig. 2, Table 4): QTL1_pathotype001 mapped in LG 2, at $17.0 \mathrm{cM}$ from marker E-CGC/MATA 1, explaining $13.4 \%$ of the phenotypic variation; QTL2_pathotype-001 mapped in LG 2, at $0 \mathrm{cM}$ from marker 
Table 3 List of mapped SSR primers and their melting temperature $\left(T_{\mathrm{m}}\right)$ and amplicon size in base pairs (bp)

\begin{tabular}{|c|c|c|c|c|c|}
\hline Primer & Forward primer & Reverse primer & $\begin{array}{l}\text { Estimated fragment } \\
\text { size }(\mathrm{pb})\end{array}$ & $\begin{array}{l}\text { Linkage group } \\
\text { mapped }\end{array}$ & Reference \\
\hline EST-SSR 001 & GAAGACCAAGCACCCTCAAC & ACACCAACTACGGGCAGACA & 151 & LG 5 & Ferrão et al. (2015) \\
\hline EST-SSR 009 & TCCGAGTCACATCCCATAAA & GGAGGAAAGTGAAGGAAGAAGA & 160 & LG 3 & Ferrão et al. (2015) \\
\hline EST-SSR 013 & GCCTTGCTCATATCTGCTGTCT & GATCCTTCAACTGAGCCAAA & 141 & LG 5 & Ferrão et al. (2015) \\
\hline EST-SSR 023 & TGTCAGTCGTCGGTCAAATC & GGTTGGACTCGCTTCTTCTTCT & 218 & LG 6 & Ferrão et al. (2015) \\
\hline EST-SSR 025 & TCCGTTCCGGGCTTATGAT & AAACAGACGCAGATCCCAGA & 224 & LG 5 & Ferrão et al. (2015) \\
\hline EST-SSR 032 & AGTCCTTGGCACTTGCTTT & CAGACAACGATCAATACCTTCC & 200 & LG 3 & Ferrão et al. (2015) \\
\hline EST-SSR 034 & GATACTTCCATGAGGATCGTTG & GATCATACAATGTGGGAAGG & 139 & LG 6 & Ferrão et al. (2015) \\
\hline EST-SSR 037 & CCTTTGAGGTGGTCAGCCTA & CCCTGATGACCTAGAGAACC & 212 & LG 5 & Ferrão et al. (2015) \\
\hline EST-SSR 046 & СССТСССТССТАСТTGTCCTAA & ATCCGGCATCATCATCAGAG & 234 & LG 11 & Ferrão et al. (2015) \\
\hline EST-SSR 050 & AAGGAGGAAGAGCGACCAAA & GCGTCAATGTTGGAAGGAAA & 162 & LG 3 & Ferrão et al. (2015) \\
\hline EST-SSR 060 & TCCTCCTCGTGCTTCTCAAC & GGCAGCATTCTCCTGATCCT & 126 & LG 5 & Ferrão et al. (2015) \\
\hline EST-SSR 061 & GAGCATGAGACACTCTCTGGAA & CATTGGGTGTTGATGGAGGA & 142 & LG 11 & Ferrão et al. (2015) \\
\hline EST-SSR 062 & CACTTAGTTCCAAAGTGCTACC & TTCCTCAACTTCCCAGGAGAT & 129 & LG 9 & Ferrão et al. (2015) \\
\hline EST-SSR 069 & TTGTGTTCTTTCTCCACCTC & CAGGAGTCGTATAACGCTGAA & 132 & LG 5 & Ferrão et al. (2015) \\
\hline EST-SSR 074 & ACAAGCCAAGGCGACTGAA & CCGTAGGGAATAGAGGAGCA & 140 & LG 9 & Ferrão et al. (2015) \\
\hline EST-SSR 077 & GCACCTGGAGGGAGACAAAT & CGCACTACCAAAAGCAGGAA & 216 & LG 9 & Ferrão et al. (2015) \\
\hline EST-SSR 096 & AGACAGCTTTGGTGGTCCTG & TGAATGTGTGGCCCTTTAGC & 223 & LG 9 & Ferrão et al. (2015) \\
\hline EST-SSR 107 & AACAAGAGTTTCTGCCTGTG & TCTCTCGAAGTAGATTGCTCTG & 159 & LG 3 & Ferrão et al. (2015) \\
\hline SSRCa 018 & GTCTCGTTTCACGCTCTCTC & ATTTTTGGCACGGTATGTTC & 115 & LG 7 & Missio et al. (2009a, b) \\
\hline SSRCa 034 & TGGACAAGAAATTGAAGTGG & GGGTTTAAATTATCGGGTGT & 257 & LG 3 & Missio et al. (2009a, b) \\
\hline SSRCa 052 & GATGGAAACCCAGAAAGTTG & TAGAAGGGCTTTGACTGGAC & 129 & LG 1 & Missio et al. (2009a, b) \\
\hline SSRCa 080 & GTTCTTTCCGCCGTCAAT & GAGAAGAGAGAGGAAGGGAAA & 250 & LG 12 & Missio et al. (2009a, b) \\
\hline SSRCa 086 & AGAGAGAAGCCATGATTTGA & TCAGTCCCAGAGAATAAGGA & 105 & LG 1 & Missio et al. (2009a, b) \\
\hline SSRCa 095 & GAGAGAGCCGAGTGAAGAGA & GAGAGAGAAGCCATGATTTGA & 185 & LG 1 & Missio et al. (2009a, b) \\
\hline SSR 004 & AGGCCTTCATCTCAAAAACC & AGCGTTACTTGAGGCAAAGA & 217 & LG 1 & Rovelli et al. (2000) \\
\hline SSR 007 & TGACATAGGGGGCTAAATTG & TTAATGGTGACGCTTTGATG & 215 & LG 8 & Rovelli et al. (2000) \\
\hline SSR 008 & CACTGGCATTAGAAAGCACC & GGCAAAGTCAATGATGACTC & 198 & LG 9 & Rovelli et al. (2000) \\
\hline SSR 009 & ATGCCAAGTCGGAAAAGAA & GGCAAGCTCTAGCCTTTGA & 136 & LG 8 & Rovelli et al. (2000) \\
\hline SSR 016 & ACCCGAAAGAAAGAACCAAG & CСАСАСААСТСТССТСАТТС & $140-146$ & LG 2 & Combes et al. (2000) \\
\hline SSR 018 & GGCTCGAGATATCTGTTTAG & TTTAATGGGCATAGGGTCC & $132-166$ & LG 1 & Combes et al. (2000) \\
\hline SSR 030 & ATGGGGCCAACTTGAATATG & CAGGGCATCTATCTACTTCTCTTT & 220 & LG 12 & Poncet et al. (2004) \\
\hline SSR 034 & GGAGACGCAGGTGGTAGAAG & TCGAGAAGTCTTGGGGTGTT & 294 & LG 5 & Poncet et al. (2004) \\
\hline SSR 035 & CTGGCATTAGAAAGCACCTTG & GCTTGGCTCACTGTAGGACTG & 158 & LG 9 & Poncet et al. (2004) \\
\hline SSR 036 & ATGCCAAGTCGGAAAAGAA & CACTAGCATAATTGCGTGGA & 157 & LG 8 & Poncet et al. (2004) \\
\hline SSR 045 & CTGAGCGCATGGAAGGAGTA & GGAGACGCAGGTGGTAGAAG & 194 & LG 5 & Poncet et al. (2004) \\
\hline SSR 057 & CTCGCTTTCACGCTCTCTCT & CGGTATGTTCCTCGTTCCTC & 102 & LG 7 & Coulibaly et al. (2003) \\
\hline SSR 067 & CGTCTCGTTTCACGCTCTCT & GATCTGCATGTACTGGTGCTTC & 237 & LG 7 & Poncet et al. (2004) \\
\hline SSR 070 & GTAACCACCACCTCCTCTGC & TGGAGGTAACGGAAGCTCTG & $167-230$ & LG 5 & Baruah et al. (2003) \\
\hline SSR 071 & GCTAAGTTCAATTGCCCCTGT & GGGTTAATTTGATTGCGTGA & $210-232$ & LG 10 & Baruah et al. (2003) \\
\hline SSR 091 & TTGCTTCGTTTTAAATGTGAGG & AATTGTCTATAAAAAAGAGAGAGA & 135 & LG 8 & Moncada and McCouch (2004) \\
\hline SSR 100 & АСССТTТАСТАСТТАТТТАСТСТС & ACATCCCCTTGCCATTTCTTC & 157 & LG 3 & Moncada and McCouch (2004) \\
\hline SSR 145 & CTGCGAGGAGGAGTTAAAGATACCAC & GCCGGGAGTCTAGGGTTCTGTG & $138-150$ & LG 5 & Bhat et al. (2005) \\
\hline SSR 156 & CGGCTCAAAGGTGCTCAAT & TCCCAATTCTTTCTTTCTTTCTGT & 135 & LG 1 & Moncada and McCouch (2004) \\
\hline CaM-25 & TCCATCTTCCTTCATTTCTGCTGCTAA & ССТТСАСССССТTTGCАСТTССТТА & 186 & LG 1 & Hendre et al. (2008) \\
\hline
\end{tabular}

E-CTG/M-AAT 1, explaining $16.2 \%$ of the phenotypic variation; QTL3 pathotype-001 mapped in LG 3, at $12.0 \mathrm{cM}$ from marker EST-SSR 050, explaining $7.5 \%$ of phenotypic variation; and QTL4 pathotype-001 mapped in LG 10, at $0 \mathrm{cM}$ from E-CGA/M-TCC 4, explaining $13.8 \%$ of phenotypic variation.

\section{Discussion}

\section{Inheritance study}

Although the inheritance study was performed by phenotyping plants in an appropriate genetic design (contrasting parents, $\mathrm{F}_{1}$, 
Table 4 Molecular markers associated with QTLs for coffee plant resistance to rust, identified by simple interval and regression analysis (LOD $>3$ ) LG Marker/QTL ${ }^{\mathrm{a}} \quad \mathrm{bp}^{\mathrm{b}} \quad$ Pos. $(\mathrm{cM}) \quad \operatorname{LOD}^{\mathrm{c}} \quad R^{2 \mathrm{~d}}(\%) \quad a^{\mathrm{e}} \quad d^{\mathrm{f}} \quad k^{\mathrm{g}} \quad$ Allelic $\quad$ Average of disease Mean severity interaction severity reduction $(\%)$

$\mathrm{A}_{1-} \quad \mathrm{A}_{2} \mathrm{~A}_{2}$

Race I

\begin{tabular}{rllrrrrrrrrrrr} 
QTL 1 & 2 & E-CGC/M-ATA 1 & 145 & 22.7 & 5.516 & 9.1 & -0.49 & -0.51 & 1.03 & CD & 2.7828 & 3.2500 & 14.4 \\
QTL 2 & 2 & E-CTG/M-AAT 1 & 670 & 3.0 & 4.941 & 8.9 & 0.39 & -1.57 & -4.11 & OD & 2.7850 & 3.2955 & 15.5 \\
QTL 3 & 3 & EST-SSR 050 & 129 & 13.0 & 3.127 & 5.7 & 0.45 & -1.87 & -4.19 & OD & 2.8529 & 2.9762 & 4.2 \\
QTL 4 & 10 & E-CGA/M-TCC 4 & 800 & 12.0 & 4.345 & 7.8 & -0.11 & -0.75 & 6.98 & OD & 2.7717 & 3.1774 & 12.8 \\
Race II & & & & & & & & & & & & & \\
QTL 1 & 2 & E-CTG/M-AAT 1 & 670 & 3.7 & 3.147 & 5.8 & -0.21 & -0.42 & 2.00 & OD & 2.4500 & 2.8864 & 15.1 \\
QTL 2 & 10 & E-CCC/M-AGA 1 & 220 & 8.0 & 4.505 & 8.1 & -0.96 & 1.16 & -1.21 & OD & 2.3846 & 3.0169 & 21.0 \\
Pathotype 001 & & & & & & & & & & & & \\
QTL 1 & 2 & E-CGC/M-ATA 1 & 145 & 17.0 & 8.071 & 13.4 & -0.71 & -0.56 & 0.79 & PD & 2.0859 & 2.8333 & 26.4 \\
QTL 2 & 2 & E-CTG/M-AAT 1 & 670 & 0.0 & 9.968 & 16.2 & -0.90 & 0.29 & -0.33 & PD & 2.0700 & 3.0000 & 31.0 \\
QTL 3 & 3 & EST-SSR 050 & 129 & 12.0 & 4.229 & 7.5 & 0.40 & -2.38 & -3.46 & OD & 2.1520 & 2.6190 & 17.8 \\
QTL 4 & 10 & E-CGA/M-TCC 4 & 800 & 0.0 & 8.351 & 13.8 & -0.80 & 0.39 & -0.48 & PD & 2.0054 & 2.9032 & 30.9 \\
\hline
\end{tabular}

$L G$ linkage group, $C D$ complete dominance, $A D$ absence of dominance, $P D$ partial dominance, $O D$ overdominance

${ }^{\text {a } I d e n t i f i e d ~ m a r k e r s ~ a s s o c i a t e d ~ w h i t ~ Q T L s ~ o f ~ r a c e s ~ I ~ a n d ~ I I ~ a n d ~ p a t h o t y p e ~} 001$

${ }^{\mathrm{b}}$ Base pairs of molecular marker

${ }^{\mathrm{c}}$ Base logarithm 10

${ }^{\mathrm{d}}$ Coefficient of determination, which corresponds to the percentage of phenotypic variation explained by QTL

${ }^{\mathrm{e}}$ Additive effect corresponding to homozygote genotypes, which assumes values -1 and 1 for qq and QQ, respectively

${ }^{\mathrm{f}}$ Dominance effect corresponding to heterozygote genotype, Qq

${ }^{g}$ Average degree of dominance, indicating incidence of different types of allelic interactions

$\mathrm{F}_{2}$, $\mathrm{BCr}$, and $\mathrm{BCs}$ ), it was not possible to conclude whether resistance of HDT UFV 443-03 to race I, race II, and pathotype 001 of $H$. vastatrix is controlled by two independent dominant loci or three independent dominant loci (two dominant and one recessive). The population sizes did not allow us to test $\left(\chi^{2}\right.$ test) if the resistance is controlled by four loci. For these reasons, QTL mapping was useful to ascertain the inheritance study.

Previous inheritance studies of HDT resistance to $H$. vastatrix reported that it was conditioned by major dominant genes. Pereira (1995), working with seven accessions of HDT and races II and XXV of $H$. vastatrix, reported that the resistance was conditioned by three independent dominant genes, in six accessions, and in one accession, the resistance was conditioned by one dominant gene. Brito et al. (2010) reported one dominant gene conditioning the resistance of HDT UFV427-15 to race II. Romero et al. (2014) reported one QTL region corresponding to a new and genetically independent $\mathrm{S}_{\mathrm{H}}$ gene of DI200, a line derived from Caturra $\times$ HDT CIFC1343, using a mix of uredospores of $H$. vastatrix field collected from Caturra cultivar.

\section{Linkage map}

SSR markers are widely used for constructing linkage maps in many species, because they are highly polymorphic, locus specific, and useful as anchors for map integration, and require a small DNA quantity for PCR (Chistiakov et al. 2006; Ball et al. 2010). SSRs can also be used as fluorescent in situ hybridization (FISH) probes for physical mapping. However, construction of a C. arabica genetic linkage map was hampered by low polymorphism level of SSR markers. Only 58 out of 373 SSR markers were polymorphic. Such low polymorphism in C. arabica was also reported by others, indicating the narrow genetic base of the species. Vieira et al. (2010) reported that 22 out of 127 SSR markers were polymorphic. Herrera et al. (2009) reported 3 out of 13 markers, and Geleta et al. (2012) reported 8 out of 12 markers.

Low polymorphism of SSR markers in C. arabica leads us to add other types of molecular markers to construct a map. Seventeen combinations of selective AFLP primers generated 74 polymorphic markers with an average of 4.3 polymorphic bands per pair of primers. Such low polymorphism was also reported by Ky et al. (2000), Pearl et al. (2004), and Brito et al. (2010), who identified 1.1, 6.5, and 1.4 polymorphic bands per primer, respectively. Forty-six RAPD primers generated only four polymorphic markers, with one polymorphic band/primer. Such low polymorphism was also reported by Teixeira-Cabral et al. (2004) and Oliveira et al. (2007), who identified 1.2 and 1.3 polymorphic bands per primer, 
respectively. Despite having low polymorphism, these markers, especially the multilocus AFLP markers, helped to construct a map encompassing $976.8 \mathrm{cM}$ of the genome.

We observed 21 markers (12 AFLP, 8 SSR, and 1 CARF $005)$ with segregation ratio distortion ( $15.3 \%$ distortion). The segregation ratio distortion may vary among species, types of markers, and types of populations. Constructing RAPD-based map for a HDT-derived population (backcross with C. arabica recurrent parent), Oliveira et al. (2007) and Teixeira-Cabral et al. (2004) reported 24.5 and $5.5 \%$ distortion, respectively. Paillard et al. (1996) reported $20 \%$ distortion of RAPD marker in C. canephora. With AFLP markers and different Coffea species, Ky et al. (2000) reported approximately $30 \%$ distortion. Pearl et al. (2004) reported $25 \%$ distortion of AFLP markers in C. arabica.

Geng et al. (2007) demonstrated that markers with segregation distortion affect genetic distance in the linkage map, causing an increase in distance between adjacent markers. However, even assuming that segregation distortion affects Mendelian segregation, Luo et al. (2005) do not recommend the exclusion of markers with segregation distortion in genetic linkage maps with the purpose of mapping QTLs. According to the authors, the exclusion of these markers might cause a loss of information if the marker with segregation distortion is associated with any QTL. Some authors do not use markers with segregation distortion for QTL mapping; nevertheless, these markers have been routinely used for QTL mapping in several studies, without important effects (Truco et al. 2007; Couto et al. 2010; Guo et al. 2013). With simulated data, Zhang et al. (2010) and Wen and Zhang (2013) observed that if the distorted marker is intimately linked with any QTL, distortion will not have a significant impact on QTL mapping.

Linkage map was constructed with 111 markers, including some with segregation distortion, which increased the map saturation. However, in the present study, markers with segregation distortion were not associated to QTLs.

Our linkage map had a mean genetic distance of $9.7 \mathrm{cM}$, which was similar to other coffee studies. Pearl et al. (2004), Teixeira-Cabral et al. (2004), and Oliveira et al. (2007) reported mean genetic distance of $10.2,7.3$, and $7.5 \mathrm{cM}$, respectively. Despite presenting few linkage gaps, our map was suitable for QTL mapping.

In this study, $247 \mathrm{~F}_{2}$ individuals were used to a construct linkage map. This population was larger than the map populations used by Paillard et al. (1996), Ky et al. (2000), Lashermes et al. (2001), Pearl et al. (2004), Teixeira-Cabral et al. (2004), and Oliveira et al. (2007). Increased accuracy in constructing genetic linkage maps can be obtained with large populations. With simulated data of $F_{2}$, recombinant-inbred lines, and backcross populations, Ferreira et al. (2006) reported that populations with 200 individuals are considered to be sufficient for the construction of reasonably precise genetic maps.

\section{Mendelian factor location}

Molecular markers linked to QTLs as explained from 5.7 to $16.2 \%$ of the phenotypic variation. Similar values were identified for QTLs associated with resistance to other diseases in different species. Siviero et al. (2006) identified QTLs, explaining a phenotypic variation from 14 to $24 \%$ for citrus gummosis. Risterucci et al. (2003) identified a phenotypic variation explained by QTLs associated with resistance to Phytophthora spp. from 7.5 to $12.4 \%$. In chickpea, Sabbavarapu et al. (2013) identified two QTLs for resistance to Fusarium oxysporum f. sp. ciceris, explaining 10.4 and $18.8 \%$ of the phenotypic variation and six QTLs for Ascochyta rabiei, with the highest phenotypic variation explained by one of the QTLs at $31.9 \%$. The authors reported that resistance to $F$. oxysporum is an oligogenic trait and that the two identified QTLs correspond to two large effect genes. However, for A. rabiei, the only QTL that explained $31.9 \%$ of the phenotypic variation corresponded to a QTL of large effect.

The phenotypic variation explained by QTL (coefficient of determination, $R^{2}$ ) can be affected by the distance of the marker to the QTL and the trait heritability. Therefore, it is possible that $R^{2}$ of markers associated with QTLs in this study was underestimated, as the marker distance from QTLs ranged from 0.0 to $22.7 \mathrm{cM}$. The refinement of QTL mapping would help to identify the putative loci. Romero et al. (2014) identified one QTL for resistance of C. arabica to H. vastatrix, explaining 52.1 to $70.3 \%$ of the phenotypic variation. They evaluated adult plants resistance using an inoculum composed of a mix of uredospores of $H$. vastatrix collected in the field and scored area of lesion, area under disease curve, and field rust data. In the other hand, we evaluated coffee leaf discs using three monopustule isolates of $H$. vastatrix and scored the race-specific resistance using a score scale based on the absence or presence of uredospores. These experimental differences may explain the different results.

It was possible to notice that the QTL located in LG 2 associated with marker E-CTG/M-AAT 1 as well as the QTL located in LG 10 associated with marker E-CCC/MAGA 1 conferred resistance to race I, race II, and pathotype 001. The QTL in LG 2 associated with marker E-CGC/MATA 1, as well as the QTL located in LG 3 between markers EST-SSR 050 and EST-SSR 107 resulted in resistance to race I and pathotype 001 . Hence, the same genes might be involved in resistance to race I and pathotype 001 or the region contains different and closely linked genes that confer resistance to them. In fact, resistance genes are frequently clustered. Clustering can be a result of duplication and recombination of one or more parental genes. Recombination between closely linked or very close genes in the chromosome may generate new pathogen recognition specificities, such as other 
resistance genes (Keen 1990). This mechanism is important for plant-pathogen co-evolution.

From the QTLs identified in the linkage map, none was recessive, showing that no recessive gene contributes to the resistance of the HDT UFV 443-03. This result rejects the hypothesis suggested in the inheritance study of the three loci (two dominant and one recessive) conferring resistance to this coffee plant. By the combination of phenotypic and genotypic data, it was concluded that at least two dominant and independent loci control the resistance of HDT UFV 443-03. For race II, two QTLs confirmed the presence of two dominant loci, conferring resistance to this race of $H$. vastatrix. However, for race I and pathotype 001, four QTLs were identified, implying that resistance of HDT UFV 443-03 to these two isolates can be controlled by four resistance loci. In the inheritance study, the population sizes did not allow us to test $\left(\chi^{2}\right.$ test $)$ if the CLR resistance is controlled by four loci.

According to the QTL mapping results, HDT UFV 443-03 has four important putative loci conditioning CLR resistance located in four genomic regions: two regions (LG 2 and LG 10) for races I and II and pathotype 001 and two other regions (LG 2 and LG 3) for race I and pathotype 001. Thus, markerassisted selection (MAS) should allow introgression of these loci into new cultivars with durable resistance to at least the three isolates (race I, race II, and pathotype 001) of $H$. vastatrix. Additional markers for CLR resistance identified by other authors (Romero et al. 2014; Prakash et al. 2004; Mahé et al. 2008; Brito et al. 2010; Diola et al. 2011) can be simultaneously used with MAS, allowing rapid and efficient identification of resistance genes in progenies without needing to evaluate the phenotype (Caixeta et al. 2009).

A high-resolution mapping of regions where the QTLs were detected should allow cloning of these CLR resistance loci. Moreover, SSR markers included in the map are useful to integrate partial coffee plant maps as an alternative to obtain a saturated map. It should aid breeding resistant and productive new cultivars.

\section{Conclusion}

The present study indicated that CLR resistance of HDT UFV 443-03 to race II of $H$. vastatrix is conditioned by at least two independent dominant loci. One locus is located in the LG 2 and the other in the LG 10 . The CLR resistance of HDT UFV 443-03 to race I and pathotype 001 is conditioned by at least four independent dominant loci. Two loci are located in the LG 2, one in the LG 3, and one in the LG 10. The same four independent loci condition the resistance to race I and pathotype 001. Two of these four independent loci also condition the resistance to race II. The best markers identified, so far, for MAS of CLR resistance loci derived from HDT UFV 443-03 were the following: E-CTG/M-AAT 1 (LG 2) and E-
CCC/M-AGA1 (LG 10) for race II and E-CGC/M-ATA 1 (LG 2), E-CTG/M-AAT 1 (LG 2), EST-SSR 050 (LG 3), and ECGA/M-TCC 4 (LG 10) for race I and pathotype 001.

Acknowledgments This work was financially supported by the Brazilian Coffee Research and Development Consortium (Consórcio Brasileiro de Pesquisa e Desenvolvimento do Café (CBP\&D/Café)), Minas Gerais State Foundation for Research Aid (FAPEMIG), National Council of Scientific and Technological Development (CNPq), and National Institutes of Science and Technology of Coffee (INCT Café).

Data Archiving Statement All oligonucleotides used in this work have been published previously (Combes et al. 2000; Rovelli et al. 2000; Baruah et al. 2003; Coulibaly et al. 2003; Moncada and McCouch 2004; Poncet et al. 2004; Bhat et al. 2005; Hendre et al. 2008; Missio et al. 2009b, 2011). Thus, their sequences are available in the respective literatures.

\section{References}

Alvarenga SM, Caixeta ET, Hufnagel B, Thiebaut F, Maciel-Zambolim E, Zambolim L, Sakiyama NS (2011) Molecular markers from coffee genome expressed sequences potentially involved in resistance to rust. Pesq Agrop Brasileira 46:890-898

Ball AD, Stapley J, Dawson DA, Birkhead TR, Burke T, Slate J (2010) A comparison of SNPs and microsatellites as linkage mapping markers: lessons from the zebra finch (Taeniopygia guttata). BMC Genomics 11:218. doi:10.1186/1471-2164-11-218

Baruah A, Naik V, Hendre PS, Rajkumar R, Rajendrakumar P, Aggarwal $R$ (2003) Isolation and characterization of nine microsatellite markers from Coffea arabica L., showing wide cross-species amplifications. Mol Ecol Notes 3:647-650. doi:10.1046/j.1471-8286. 2003.00544.x

Berthaud J, Charrier A (1988) Genetic resources of Coffea. In: R.J. C, R. $\mathrm{M}$ (eds) Coffee, London, pp 1-42

Bettencourt AJ, Carvalho A (1968) Melhoramento visando a resistência do cafeeiro à ferrugem. Bragantia 27:35-68

Bettencourt AJ, Noronha-Wagner M (1971) Genetic factors conditioning resistance of Coffea arabica L. to Hemileia vastatrix Berk. \& Br. Agron Lusit 31:285-292

Bettencourt AJ, Rodrigues CJ Jr (1988) Principles and practice of coffee breeding for resistance to rust and other diseases. Coffee Agron 4: 199-234

Bettencourt AJ, Noronha-Wagner M, Lopes M (1980) Factor genético que condiciona a resistência do clone 1343/269 (Híbrido de Timor) à Hemileia vastatrix Berk. and Br. Brotéria Genética 1

Bettencourt AJ, Lopes J, Palma S (1992) Fatores genéticos que condicionam a resistência às raças de Hemileia vastatrix Berk. et $\mathrm{Br}$ dos clones-tipo dos grupos 1, 2 e 3 de derivados de Híbrido de Timor. Brotéria Genética 13:185-194

Bhat PR, Krishnakumar V, Hendre PS, Rajendrakumar P, Varshney RK, Aggarwal RK (2005) Identification and characterization of expressed sequence tags-derived simple sequence repeats markers from robusta coffee variety 'CxR' (an interspecific hybrid of Coffea canephora $\times$ Coffea congensis). Mol Ecol Notes 5:80-83. doi:10. 1111/j.1471-8286.2004.00839.x

Brito GG, Caixeta ET, Gallina AP, Zambolim EM, Zambolim L, Diola V, Loureiro ME (2010) Inheritance of coffee leaf rust resistance and identification of AFLP markers linked to the resistance gene. Euphytica 173:255-264. doi:10.1007/s10681-010-0119-x

Cabral PGC, Zambolim EM, Zambolim L, Lelis TP, Capucho AS, Caixeta ET (2009) Identification of a new race of Hemileia vastatrix 
in Brazil. Australasian Plant Dis Notes 4:129-130. doi:10.1071/ DN09052

Caixeta ET, Oliveira ACB, Brito GG (2009) Tipos de marcadores moleculares. In: Borém A, Caixeta ET (eds) Marcadores moleculares, 2nd edn. Folha de Viçosa, Viçosa, pp 11-93

Capucho AS, Caixeta ET, Maciel-Zambolim E, Zambolim L (2009) Herança da resistência do Híbrido de Timor UFV 443-03 à ferrugem-do-cafeeiro. Pesq Agrop Brasileira 44:276-282

Capucho AS, Maciel-Zambolim E, Freitas RL, Haddad F, Caixeta ET, Zambolim L (2012) Identification of race XXXIII of Hemileia vastatrix on Coffea arabica Catimor derivatives in Brazil. Australasian Plant Dis Notes 7:189-191. doi:10.1007/s13314-0120081-7

Chistiakov DA, Hellemans B, Volckaert FAM (2006) Microsatellites and their genomic distribution, evolution, function and applications: a review with special reference to fish genetics. Aquaculture 255:129. doi:10.1016/j.aquaculture.2005.11.031

Combes M-C, Andrzejewski S, Anthony F, Bertrand B, Rovelli P, Graziosi G, Lashermes P (2000) Characterization of microsatellite loci in Coffea arabica and related coffee species. Mol Ecol 9:11781180. doi:10.1046/j.1365-294x.2000.00954-5.x

Coulibaly I, Revol B, Noirot M, Poncet V, Lorieux M, Carasco-Lacombe C, Minier J, Dufour M, Hamon P (2003) AFLP and SSR polymorphism in a Coffea interspecific backcross progeny [ $($ C. heterocalyx $\times$ C. canephora $) \times$ C. canephora]. Theor Appl Genet 107:1148-1155. doi:10.1007/s00122-003-1355-4

Couto KR, Santos JB, Ramalho MAP, Silva GS (2010) Identification of microsatellite markers associated with seed-coat darkening in common bean. Pesq Agrop Brasileira 45:1268-1274

Cruz CD (2008) Programa GQMOL — Genética quantitativa e molecular. Universidade Federal de Viçosa, www.ufv.br/dbg/gqmol/gqmol.htm

Cruz CD (2013) GENES - a software package for analysis in experimental statistics and quantitative genetics. Acta Sci 35(3):271-276

Diniz LEC, Sakiyama NS, Lashermes P, Caixeta ET, Oliveira ACB, Zambolim EM, Loureiro ME, Pereira AA, Zambolim L (2005) Analysis of AFLP markers associated to the Mex-1 resistance locus in Icatu progenies. Crop Breed Appl Biotechnol 5:387-393

Diola V, Brito GG, Caixeta ET, Maciel-Zambolim E, Sakiyama NS, Loureiro ME (2011) High-density genetic mapping for coffee leaf rust resistance. Tree Genet Genomes 7:1199-1208. doi:10.1007/ s11295-011-0406-2

Eskes AB (1982) The use of leaf disk inoculations in assessing resistance to coffee leaf rust (Hemileia vastatrix). Neth J Plant Pathol 88:127141

Eskes AB, Da Costa WM (1983) 8. Characterization of incomplete resistance to Hemileia vastatrix in the icatu coffee population. Euphytica 32:649-657

Eskes AB, Hoogstraten JGJ, Toma-Braghini M, Carvalho A (1990) Racespecificity and inheritance of incomplete resistance to coffee leaf rust in some Icatu coffee progenies and derivatives of Hibrido de Timor. Euphytica 47:11-19

Ferrão LFV, Caixeta ET, Souza FF, Maciel-Zambolim E, Cruz CD, Zambolim L, Sakiyama NS (2013) Comparative study of different molecular markers for classifying and establishing genetic relationships in Coffea canephora. Plant Syst Evol 299:225-238. doi:10. 1007/s00606-012-0717-2

Ferrão LFV, Caixeta ET, Pena G, Maciel-Zambolim E, Cruz CD, Zambolim L, Ferrão MAG, Sakiyama NS (2015) New EST-SSR markers of Coffea arabica: transferability and application to studies of molecular characterization and genetic mapping. Mol Breed 35: 31. doi:10.1007/s11032-015-0247-z

Ferreira A, Silva MF, Silva LDCE, Cruz CD (2006) Estimating the effects of population size and type on the accuracy of genetic maps. Genet Mol Biol 29:187-192

Geleta M, Herrera I, Monzón A, Bryngelsson T (2012) Genetic diversity of arabica coffee (Coffea arabica L.) in Nicaragua as estimated by simple sequence repeat markers. The Scientific World Journal 2012, article ID 939820. doi: 10.1100/2012/939820

Geng J-F, Zhu C-S, Zhang X-W, Cheng Y, Zhang Y-M, Hou X-L (2007) A genetic linkage map of nonheading Chinese cabbage. J Am Soc Hortic Sci 132:816-823

Guo LL, Liu XJ, Liu XC, Yang ZM, Kong DY, He YJ, Feng ZY (2013) The construction of molecular genetic map of Barley using SRAP markers. Advance in Barley Sciences. Springer, pp. 433-440. doi: 10.1007/978-94-007-4682-4_37

Hendre PS, Phanindranath R, Annapurna V, Lalremruata A, Aggarwal RK (2008) Development of new genomic microsatellite markers from robusta coffee (Coffea canephora Pierre ex A. Froehner) showing broad cross-species transferability and utility in genetic studies. BMC Plant Biol 8:51. doi:10.1186/1471-2229-8-51

Herrera JC, Alvarado AG, Cortina GHA, Combes M-C, Romero GG, Lashermes P (2009) Genetic analysis of partial resistance to coffee leaf rust (Hemileia vastatrix Berk \& Br.) introgressed into the cultivated Coffea arabica $\mathrm{L}$. from the diploid $C$. canephora species. Euphytica 167:57-67. doi:10.1007/s10681-008-9860-9

Keen NT (1990) Gene-for-gene complementarity in plant-pathogen interactions. Annu Rev Genet 24:447-463

Kochko A, Akaffou S, Andrade AC, Campa C, Crouzillat D, Guyot R, Hamon P, Ming R, Mueller LA, Poncet V, Tranchant-Dubreuil C, Hamon S (2010) Advances in Coffea genomics. Adv Bot Res 53: 23-63. doi:10.1016/S0065-2296(10)53002-7

Ky C-L, Barre P, Lorieux M, Trouslot P, Akaffou S, Louarn J, Charrier A, Hamon S, Noirot M (2000) Interspecific genetic linkage map, segregation distortion and genetic conversion in coffee (Coffea sp.). Theor Appl Genet 101:669-676. doi:10.1007/s001220051529

Lander ES, Botstein D (1989) Mapping Mendelian factors underlying quantitative traits using RFLP linkage maps. Genetics 121:185-199

Lashermes P, Combes M-C, Robert J, Trouslot P, D'Hont A, Anthony F, Charrier A (1999) Molecular characterisation and origin of the Coffea arabica L. genome. Mol Gen Genet 261:259-266. doi:10. 1007/s004380050965

Lashermes P, Combes M-C, Prakash NS, Trouslot P, Lorieux M, Charrier A (2001) Genetic linkage map of Coffea canephora: effect of segregation distortion and analysis of recombination rate in male and female meioses. Genome 44:589-595

Luo L, Zhang YM, Xu S (2005) A quantitative genetics model for viability selection. Heredity 94:347-355

Mahé L, Combes M-C, Várzea VMP, Guilhaumon C, Lashermes P (2008) Development of sequence characterized DNA markers linked to leaf rust (Hemileia vastatrix) resistance in coffee (Coffea arabica L.). Mol Breed 21:105-113. doi:10.1007/s11032-0079112-z

Maia TA, Maciel-Zambolim E, Caixeta ET, Mizubuti ESG, Zambolim L (2013) The population structure of Hemileia vastatrix in Brazil inferred from AFLP. Australas Plant Pathol 42:533-542. doi:10.1007/ s13313-013-0213-3

Missio RF, Caixeta ET, Zambolim EM, Pena GF, Ribeiro AP, Zambolim L, Pereira AA, Sakiyama NS (2009a) Assessment of EST-SSR markers for genetic analysis on coffee. Bragantia 68:573-581

Missio RF, Caixeta ET, Zambolim EM, Zambolim L, Sakiyama NS (2009b) Development and validation of SSR markers for Coffea arabica L. Crop Breed Appl Biotechnol 9:361-371

Missio RF, Caixeta ET, Zambolim EM, Pena GF, Zambolim L, Dias LAS, Sakiyama NS (2011) Genetic characterization of an elite coffee germplasm assessed by gSSR and EST-SSR markers. Genet Mol Res 10:2366-2381

Moncada P, McCouch S (2004) Simple sequence repeat diversity in diploid and tetraploid Coffea species. Genome 47:501-509

Noronha-Wagner M, Bettencourt AJ (1967) Genetic study of the resistance of Coffea sp to leaf rust 1. Identification and behavior of four factors conditioning disease reaction in Coffea arabica to twelve physiologic races of Hemileia vastatrix. Can J Bot 45:2021-2031 
Oliveira ACB, Sakiyama NS, Caixeta ET, Zambolim EM, Rufino RJN, Zambolim L (2007) Partial map of Coffea arabica L. and recovery of the recurrent parent in backcross progenies. Crop Breed Appl Biotechnol 7:196-203

Owuor JBO, Van der Vossen HAM (1981) Interspecific hybridization between Coffea arabica L. and tetraploid Coffea canephora Pierre: I: fertility in F1 hybrids and backcrosses to C. arabica. Euphytica 30:861-866

Paillard M, Lashermes P, Pétiard V (1996) Construction of a molecular linkage map in coffee. Theor Appl Genet 93:41-47. doi:10.1007/ BF00225725

Pearl HM, Nagai C, Moore PH, Steiger DL, Osgood RV, Ming R (2004) Construction of a genetic map for arabica coffee. Theor Appl Genet 108:829-835. doi:10.1007/s00122-003-1498-3

Pereira AA (1995) Herança da resistência a Hemileia vastatrix Berk. et Br. em cafeeiros derivados do Híbrido de Timor. Universidade Federal de Viçosa, Dissertation

Poncet V, Hamon P, Minier J, Carasco C, Hamon S, Noirot M (2004) SSR cross-amplification and variation within coffee trees (Coffea spp.). Genome 47:1071-1081

Prakash NS, Marques DV, Varzea VMP, Silva MC, Combes M-C, Lashermes P (2004) Introgression molecular analysis of a leaf rust resistance gene from Coffea liberica into C. arabica L. Theor Appl Genet 109:1311-1317. doi:10.1007/s00122-004-1748-z

Risterucci AM, Paulin D, Ducamp M, N'goran JAK, Lanaud C (2003) Identification of QTLs related to cocoa resistance to three species of Phytophthora. Theor Appl Genet 108:168-174. doi:10.1007/ s00122-003-1408-8

Rodrigues CJ Jr, Bettencourt AJ, Rijo L (1975) Races of the pathogen and resistance to coffee rust. Annu Rev Phytopathol 13:49-70

Romero GG, Alvarado GA, Cortina HG, Ligarreto GM, Galeano NF, Herrera JCP (2010) Partial resistance to leaf rust (Hemileia vastatrix) in coffee (Coffea arabica $\mathrm{L}$.): genetic analysis and molecular characterization of putative candidate genes. Mol Breed 25: 685-697

Romero GG, Vásquez LM, Lashermes P, Herrera JCP (2014) Identification of a major QTL for adult plant resistance to coffee leaf rust (Hemileia vastatrix) in the natural Timor hybrid (Coffea arabica $\mathrm{x}$ C. canephora). Plant Breed 133:121-129

Rovelli P, Mettulio R, Anthony F, Anzueto F, Lashermes P, Graziosi G (2000) Microsatellites in Coffea arabica L. In: Sera T, Soccol CR, Pandey A, Roussos S. (eds) Coffee biotechnology and quality. Springer, pp 123-133
Sabbavarapu MM, Sharma M, Chamarthi SK, Swapna N, Rathore A, Thudi M, Gaur PM, Pande S, Singh S, Kaur L (2013) Molecular mapping of QTLs for resistance to Fusarium wilt (race 1) and Ascochyta blight in chickpea (Cicer arietinum L.). Euphytica 193: 121-133. doi:10.1007/s10681-013-0959-2

Siviero A, Cristofani M, Furtado EL, Garcia AAF, Coelho ASG, Machado MA (2006) Identification of QTLs associated with citrus resistance to Phytophthora gummosis. J Appl Genet 47(1):23-28. doi:10.1007/BF03194595

Tamayo PJ, Vale FXR, Zambolim L, Chaves GM, Pereira AA (1995) Resistência do Catimor à ferrugem e virulência de raças fisiológicas de Hemileia vastatrix Berk. \& Br. Fitopatol Bras 20: $572-576$

Teixeira-Cabral TA, Sakiyama NS, Zambolim L, Pereira AA, Schuster I (2004) Single-locus inheritance and partial linkage map of Coffea arabica L. Crop Breed Appl Biotechnol 4:416-421

Truco MJ, Antonise R, Lavelle D, Ochoa O, Kozik A, Witsenboer H, Fort SB, Jeuken MJW, Kesseli RV, Lindhout P (2007) A high-density, integrated genetic linkage map of lettuce (Lactuca spp.). Theor Appl Genet 115:735-746. doi:10.1007/s00122-007-0599-9

Várzea VMP, Marques DV (2005) Population variability of Hemileia vastatrix vs. coffee durable resistance. In: Zambolim L, Zambolim E, Várzea VMP (eds) Durable resistance to coffee leaf rust. Suprema Gráfica, Viçosa, pp 53-74

Vieira ESN, Von Pinho ÉVR, Carvalho MGG, Esselink DG, Vosman B (2010) Development of microsatellite markers for identifying Brazilian Coffea arabica varieties. Genet Mol Biol 33:507-514

Voorrips RE (2002) MapChart: software for the graphical presentation of linkage maps and QTLs. J Hered 93:77-78

Wagner M, Bettencourt AJ (1965) Inheritance of reaction to Hemileia vastatrix Berk \& Br. in Coffea arabica. Progress report 19601965. Coffee Rusts Research Center, Oeiras, Portugal

Wen J, Zhang Y-M (2013) Multi-QTL mapping for quantitative traits using distorted markers. Mol Breed 31:395-404. doi:10.1007/ s11032-012-9797-5

Zambolim L, Vale FXR, Pereira AA, Chaves GM (1999) Manejo integrado das doenças do cafeeiro. In: Zambolim L (ed) Produção de café com qualidade. UFV, Viçosa, pp 134-215

Zhang L, Wang S, Li H, Deng Q, Zheng A, Li S, Li P, Li Z, Wang J (2010) Effects of missing marker and segregation distortion on QTL mapping in F2 populations. Theor Appl Genet 121:1071-1082. doi:10. 1007/s00122-010-1372-z 